\title{
KAJIAN BAHASA RUPA PADABATIK GENDONGAN LASEM MOTIF POHON HAYAT DAN SATWA
}

\author{
Morinta Rosandini \\ Program Studi Kriya \\ Universitas Telkom \\ Jl. Telekomunikasi No.1, Terusan Buah Batu, 40257 \\ Email:morintarosandini@telkomuniversity.ac.id \\ Yuki Kireina \\ Program Studi Kriya \\ Universitas Telkom \\ Jl. Telekomunikasi No.1, Terusan Buah Batu, 40257 \\ Email:yukikireina@student.telkomuniversity.ac.id
}

\begin{abstract}
ABSTRAK
Batik Gendongan Lasem merupakan salah satu produk budaya Indonesia yang saat ini keberadaannya sudah mulai hilang, hal tersebut terlihat dari menurunnya jumlah produksi kain batik gedongan di daerah Lasem, serta kerumitan motif serta teknik pembuatannya menambah faktor kelangkaan. Dalam upaya mengenalkan visual motif serta makna dan memaknai unsur desain yang terkandung pada batik gendongan asal lasem, kajian bahasa rupa pada motif batik ini diperlukan. Penelitian ini menggunakan pendekatan analisa wimba pada unsur bagian motif batik. Hasil penelitian menunjukkan bahwa motif-motif pada batik gendongan asal lasem memiliki karakter stilasi primitif dan mengisahkan cerita tentang keharmonisan alam yang memiliki makna cerita tentang doa-doa kebaikan bagi pemakai (ibu dan anak). Studi visual bahasa rupa ini dapat dijadikan acuan bagi para desainer untuk mengembangkan desain motif sebagai inspirasi berkarya agar batik gendongan Lasem dapat dikenal lebih luas
\end{abstract}

Kata kunci: bahasa, batik, gendongan, dan lasem.

\section{ABSTRACT}

Batik Gendongan Lasem is one of the Indonesia's cultural products which is currently being lost. It can be seen from the declining number of gendongan (carrying on back with cloth) batik production in Lasem area, as well as the complexity of the motives and the manufacturing techniques that also cause the scarcity. The study of visual language on batik motives is needed to introduce visual motives, meanings, and interpretation of the design elements contained in the gendongan batik of lasem. This study uses the approach of the Wimba analysis on the elements of batik motives. The results show that the motives on the gendongan batik from Lasem have primitive style. It tells the stories about the harmony of nature which has good wishes for the user (mother and child). The visual studies of visual language can be used as a reference for designers, as well as their inspirations, to develop the motives designs so that Lasem gendongan batik can be widely known.

Keywords: language, batik, gendongan, Lasem.

\section{A. Pengantar}

Batik Lasem termasuk kedalam batik klasik, tercatat bahwa produksi batik Lasem sudah dimulai seja tahun 1415 diperkenalkan oleh seorang keturunan Tionghoa yang tinggal di daerah Lasem pada masa tersebut (Kusrianto, 2013). Batik kemudian semakin membudaya di daerah Lasem, menjadikan daerah tersebut memiiki ciri khas Batik yang kuat. Industri batik lasem masik eksis hingga kini, sempat mengalami pasang surut, namun menurut Rahayu (2008) Batik Lasem mengalami kejayaanya pada akhir abd 19 hingga akhir tahun 1970-an. Lasem masuk kedalam enam besar industri batik pada masa HindiaBelanda, pada masa itu hamper $90 \%$ penduduk Lasem, khususnya perempuan keturunan Tionghoa, bekerja sebagai pengrajin batik. Namun, saat ini terdata hanya tersisa $10 \%$ masyarakat yang menggerakkan industri 
batik Lasem. Faktor menurunnya produksi batik di Lasem adalah akibat adanya krisis, kekurangan modal dan kurang nya kesadaran para penerus usaha batik, dalam hal ini anak muda (Rahayu, 2008).

Pada tahun 2009 UNESCO mengakui batik sebagai Intangible Heritage of Indonesia, hal ini mendorong pemerintah daerah untuk mengembangkan batik sebagai ciri khas daerah. Keputusan tersebut berdampak baik bagi para pengusaha batik Lasem, suntikan modal serta adanya upaya kreatif dan inovatif dari para pengusaha batik pribumi di Lasem membangkitkan kembali geliat usaha batik Lasem (Maulany, 2017). Hal menarik yang muncul dari kebangkitan industri batik ini adalah adanya pergeseran karakter dan makna dari batik itu sendiri. Batik Lasem yang berkembang saat ini Sebagian besar menjadi benda komoditi masyarakat, sedangkan pada masa kejayaannya dahulu batik menjadi simbol perjalanan kehidupan masyarakat. Terlihat dari langkanya beberapa jenis batik yang sudah tidak diproduksi lagi di Lasem, salah satunya adalah kain batik Gendongan.

Kain Gendongan pada masa lampau menjadi salah satu bagian penting dalam kehidupan orang Jawa, bayi dibuai dan di gendong dalam balutan batik (Ishwara, 2011). Menurut Heringa (1996) dalam Ishwara (2011) kain selendang untuk gendongan biasa disebut sebagai 'sayut' yang artinya "membalut", sedangkan dalam bahasa Jawa Kuno, 'sayut' berarti menolak bala. Keunikan dari 'sayut' asal Lasem yang digunakan untuk menggendong anak adalah pada ornament penyusun nya, dimana pada setiap motifnya memberikan doa dan pengharapan yang baik bagi anak yang digendong. Ciri khas motif kain gendongan Lasem adalah motif yang banyak dipengrahui oleh kebudayaan Cina, seperti motif hewan, gajah, burung hong, kilin, serta motif flora seperti bunga teratai, bunga peony, dan sulur. Motif-motif tersebut memiliki makna baik bagi pemakainya (Ishwara, 2011).

Saat ini kain 'sayut' sudah sangat jarang diproduksi, terlebih pada jenis 'sayut' klasik. Hal ini dikarenakan masyarakat modern saat ini sudah jarang menggunakan kain gendongan batik dalam keseharian, produk substitusi gendongan lainnya lebih praktis digunakan. Teknik produksi batik gendongan ini pun terbilang rumit, sehingga tidka banyak pengrajin yang memproduksi kain tersebut. Padahal jika dilihat dari unsur estetika visual yang terkandung di dalam kain batik gendongan tersebut memiliki potensi pegembangan yang besar untuk dapat dikembangkan pada kain batik Lasem, baik itu kain gendongan, maupun kain batik pada umumnya serta dapat juga diterapkan kedalam produk-produk desain modern lainnya.

Dalam upaya pengenalan kembali keunikan batik klasik Lasem, khususnya kain batik gendongan, diperlukan adanya analisa lebih dalam mengenai unsur visual pada kain batik gendongan Lasem. Diantara banyaknya referensi kain batik gendongan Lasem, penulis memilih satu kain batik gendongan yaitu kain batik gendongan dengan motif pohon hayat dan satwa. Metoda analisa yang dilakukan adalah dengan menjabarkan visual motif dengan teori bahasa rupa, menggali satu persatu makna dari isi wimba dengan membaca cara wimba dan tata ungkapan yang ada pada setiap motif yang tersaji. Hal ini dilakukan untuk mengungkap makna batik kain gendongan secara utuh dan memberikan referensi desain lanjutan.

\section{B. Kain Batik Gendongan Lasem}

\section{Analisa Visual Ornamen Batik Kain Gendongan Lasem}

Ornamen pada kain Batik Gendongan Lasem memiliki beragam jenis, pada penelitian ini dibatasi pada pembahasan satu artefak batik gendongan klasik Lasem yaitu Kain Batik Gendongan dengan motif Pohon Hayat dan Satwa. Menurut Hout (2005) pada umumnya kain batik gendongan terdiri dari empat bagian penting :

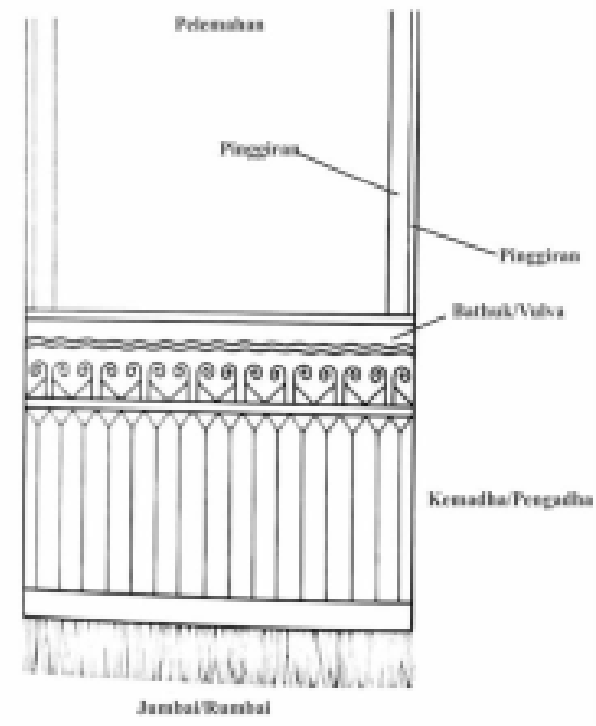

Gambar 1. Bagian kain batik gendongan. (sumber : Hout , 2005)

Bagian utamanya yaitu pelemahan, terletak di tengah kain dan menjadi bagian terbesar, bagian pinggiran sebagai frame, bagian garis yang 


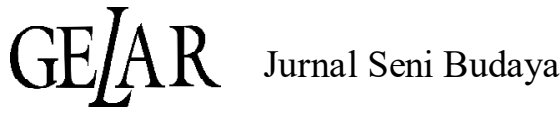

bergelombang bathuk/vulva, bagian kemadha yang merupakan garis vertikal dan bagian jumbai/rumbai, pada batik Lasem tidak terdapat rumbai diujungnya. Bagian pelemahan pada kain batik gendongan Lasem motif pohon hayat dan satwa menjadi bagian yang akan dibahas pada penelitian ini, dikarenakan pada bagian tersebut sebagian besar motif tergambar disana.

Disamping itu pula, kain batik gendongan lasem motif pohon hayat dan satwa, dipilih karena visualnya yang kuat dan banyak dipengaruhi oleh kebudayaan cina dan india, serta memiliki ciri khas warna batik Lasem yang kuat (warna merah, biru dan sogan). Berikut adalah visual dari kain batik gendongan lasem motif pohon hayat dan satwa :

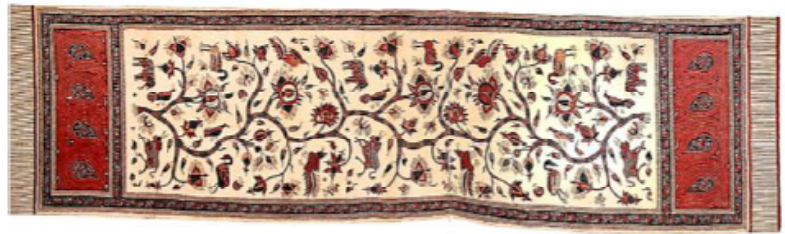

Gambar 2. Kain Batik Gendongan Lasem Motif Pohon Hayat dan satwa (sumber : Ishwara, 2005)

Kain batik gendongan lasem motif pohon hayat dan satwa termasuk kedalam artefak lama, berdasarkan Ishwara (2011) dalam bukunya diungkap bahwa tahun pembuatan batik tersebut berkisar pada tahun 1890/1900. Pada masa itu karakter penggambaran seni batik di Lasem masih dipengaruhi oleh budaya Cina, Jawa dan Hindu (Kusrianto : 2013, 223). Seni batik pada masa itu bukan hanya menyoal tentang estetika, namun sebuah media komunikasi pengrajin batik dalam menyampaikan makna kehidupan. Komunikasi tersebut disampaikan melalui simbol-simbol konkret yang dituangkan dalam selembar kain batik (Kusrianto:2013,3). Begitu pula yang tertampak dan tersirat pada kain batik gandongan lasem motif pohon hayat dan satwa. Didalamnya terdapat kandungan makna berupa cerita dari pencipta batik terdahulu.

Analisa kain batik gendongan lasem motif pohon hayat dan satwa dilakukan dengan membaca ornamennya dengan teori bahasa rupa. Teori ini digunakan karena (1) pengrauh budaya komunikasi timur (Jawa, Cina, dan Hindia) yang kuat ada pada kain batik gendongan Lasem motif Pohon Hayat dan Satwa, (2) cara penggambarannya secara keseluruhan visual, khususnya pada bagian utama motif kain batiknya, dapat terlihat adanya karakter penggayaan gambar dengan sistem menggambar ruang-waktudatar (RWD).

Menurut Tabrani (2005) dalam bukunya Bahasa Rupa :

Ciri-ciri gambar RWD : gambar 'ditembak'/ di 'shoot' dari aneka arah, aneka jarak, dan waktu. Gambarnya jadi sebuah sekuen yang ber-matra waktu dan bisa berdiri dari beberapa adegan dengan objek-objek yang bisa bergerak dalam ruang dan waktu. (Tabrani, 2005: 100).

Ornamen pada kain Batik Gendongan Lasem motif pohon hayat dan satwa memenuhi karakter RWD dimana gambar motifnya dapat dilihat dari berbagai arah, adanya variasi jarak, serta objek motifnya bercerita tak berbatas waktu. Lebih dalam akan dijelaskan pada bagian analisa bahasa rupa batik pada bab selanjutnya.

Pada bahasa rupa unsur yang menyusun nya adalah wimba (image) dan tata ungkapan (sama halnya seperti grammar pada bahasa kata). Sedangkan pada wimba terdiri dari Isi Wimba dan Cara Wimba. Isi Wimba adalah objek gambarnya sedangkan cara wimba adalah cara sebuah objek digambarkan. Tata ungkapan adalah cara menyusun wimba pada sebuah satu kesuatuan, tata ungkapan inilah yang membuat sebuah gambar memiliki cerita (Tabrani : 2005, 102).

Tahapan pertama untuk mengetahui bahasa rupa apa dan cerita apa yang tersirat pada kain batik gendongan lasem motif pohon hayat dan satwa, adalah dengan menjabarkan satu persatu Isi Wimba. Berikut tabel penjabaran /si Wimba pada kain batik gendongan Lasem motif pohon hayat dan satwa khusus pada bagian pelemahan atau bagian tengah utamanya. Isi Wimba dijabarkan berdasarkan nama motif , jenis motif dan makna motif.

\section{Isi Wimba dan Makna Mitos pada Kain Batik Gendongan Lasem}

Jenis motif batik, khususnya batik klasik/ keraton dengan unsur alam seperti yang ada di kain batik gendongan lasem, dapat dibagi menjadi tiga jenis, yaitu motif batik semen, motif batik sawat, dan motif batik alas-alasan (Pujiyanto : 2003, 129). Berikut hasil analisa isi wimba pada kain batik gendongan lasem : 
Tabel 1. Isi Wimba pada Kain Batik Gendongan Lasem Pohon hayat dan satwa

\begin{tabular}{|c|c|}
\hline $\begin{array}{c}\text { Isi Wimba, Nama dan Jenis } \\
\text { Motif }\end{array}$ & Makna Motif \\
\hline Motif Pohon Hayat (Motif & $\begin{array}{l}\text { Pengharapan } \\
\text { manusia dalam } \\
\text { kehidupanya } \\
\text { untuk } \\
\text { mencapai } \\
\text { kesempurnaan, } \\
\text { dan sulur } \\
\text { melambankan } \\
\text { umur panjang } \\
\text { (Kusrianto, } \\
\text { 2013). Sumber } \\
\text { kehidupan, } \\
\text { kekayaan dan } \\
\text { kemakmuran } \\
\text { (Hoop (1949) } \\
\text { dalam } \\
\text { Pujiyanto } \\
\text { (2003). }\end{array}$ \\
\hline & \multirow{3}{*}{$\begin{array}{l}\text { Bunga Botana } \\
\text { atau bunga } \\
\text { peony, disebut } \\
\text { fu-gui hua, } \\
\text { merupakan } \\
\text { bunga } \\
\text { kekayaan dan } \\
\text { kehormatan. } \\
\text { Bermakna } \\
\text { kebahagiaan, } \\
\text { kesetiaan, } \\
\text { kecantikan } \\
\text { abadi, dan } \\
\text { umur panjang } \\
\text { (Sumarsono, } \\
\text { 2011). Di } \\
\text { Indonesia } \\
\text { Peoni } \\
\text { disamakan } \\
\text { dengan bunga } \\
\text { teratai } \\
\text { (Rahayu, 2014) }\end{array}$} \\
\hline & \\
\hline $\begin{array}{c}\text { Motif Bunga Peony (Motif } \\
\text { Semen) }\end{array}$ & \\
\hline & \multirow[t]{2}{*}{$\begin{array}{l}\text { Melambangkan } \\
\text { kekuatan, } \\
\text { moral yang } \\
\text { tinggi dan } \\
\text { kesabaran } \\
\text { (Ishwara, } \\
\text { 2011). }\end{array}$} \\
\hline $\begin{array}{l}\text { Motif Gajah (Motif Alas- } \\
\text { alasan) }\end{array}$ & \\
\hline
\end{tabular}

\begin{tabular}{|c|c|}
\hline $2 \pi$ & \multirow[t]{2}{*}{$\begin{array}{l}\text { Kesetiaan } \\
\text { suami-istri dan } \\
\text { kebahagiaan } \\
\text { dalam } \\
\text { pernikahan } \\
\text { (Sumarsono, } \\
\text { 2011) }\end{array}$} \\
\hline $\begin{array}{c}\text { Motif Bebek (Motif Alas- } \\
\text { alasan) }\end{array}$ & \\
\hline & $\begin{array}{l}\text { Simbol } \\
\text { keyakinan dan } \\
\text { kesiap-siagaan } \\
\text { (Rahayu, } \\
\text { 2014). }\end{array}$ \\
\hline \multicolumn{2}{|l|}{$\begin{array}{l}\text { Motif Ayam (Motif Alas- } \\
\text { alasan) }\end{array}$} \\
\hline & $\begin{array}{l}\text { Melambangkan } \\
\text { kedatangan } \\
\text { musim } \\
\text { semi/hujan, } \\
\text { membawa } \\
\text { harapan dan } \\
\text { juga } \\
\text { ketenangan } \\
\text { hidup seperti di } \\
\text { pedesaan } \\
\text { (Sumarsono, } \\
\text { 2011) }\end{array}$ \\
\hline \multicolumn{2}{|l|}{$\begin{array}{c}\text { Motif Kerbau (Motif Alas- } \\
\text { alasan) }\end{array}$} \\
\hline & \multirow[t]{2}{*}{$\begin{array}{l}\text { Melambangkan } \\
\text { kebaikan dan } \\
\text { keberhasilan } \\
\text { (Ishwara, } \\
\text { 2011). } \\
\text { Merupakan } \\
\text { binatang } \\
\text { surgawi, raja } \\
\text { dari segala } \\
\text { burung yang } \\
\text { bebas dari } \\
\text { penderitaan } \\
\text { (Rahayu, 2014) }\end{array}$} \\
\hline $\begin{array}{c}\text { Motif Burung Hong (Motif } \\
\text { Alas-alasan) }\end{array}$ & \\
\hline & $\begin{array}{l}\text { Melambangkan } \\
\text { kebahagiaan } \\
\text { dan } \\
\text { kegembiraan } \\
\text { (Sumarsono, } \\
\text { 2011) }\end{array}$ \\
\hline $\begin{array}{l}\text { Motif Burung Huk (Motif } \\
\text { Alas-alasan) }\end{array}$ & \\
\hline
\end{tabular}




\section{GEEAR Jumal Scri Bublya}

\begin{tabular}{|c|l|}
\hline $\begin{array}{c}\text { Motif Kupu-kupu (Motif Alas- } \\
\text { alasan) }\end{array}$ & $\begin{array}{l}\text { Melambangkan } \\
\text { cinta kasih } \\
\text { (Ishwara, } \\
\text { 2011). }\end{array}$ \\
\cline { 1 - 2 } & $\begin{array}{l}\text { Melambangkan } \\
\text { pengusir roh } \\
\text { jahat } \\
\text { (Sumarsono, } \\
\text { 2011). }\end{array}$ \\
\hline $\begin{array}{c}\text { Motif Kalajengking (Motif } \\
\text { Alas-alasan) }\end{array}$ & \\
\hline
\end{tabular}

Dari tabel tersebut dapat ditarik kesimpulan bahwa :

(1) Kain batik gendongan lasem motif pohon hayat dan satwa, memiliki didominasi oleh motif jenis semen dan alas-alasan. Artinya motif alam adalah unsur utama pada motifnya, hal ini memperkuat bahwa kain batik gendongan ini dibuat pada masa keraton Jawa masih berkuasa, masuk kedalam batik klasik.

(2) Makna motif yang terkandung didalamnya, memiliki makna yang erat berkaitan dengan kesuburan, kemakmuran dan kebahagaan serta doadoa yang baik, hal ini mengungkapkan harapan yang baik bagi yang memakainya, baik ibu yang menggendong maupun anak yang digendong.

Dari unsur isi wimba tersebut masih dibahas terpisah, sehingga pengamatan dapat dilanjutkan dengan analisa makna yang lebih holistik terkandung didalam kain batik gendongan lasem. Makna ini dapat digali lebih lanjut dengan meneliti tata ungkapan pada wimba kain batik gendongan lasem, dengan cara membaca kaitan antar isi wimba yang ada.

\section{Cara Wimba dan Tata Ungkapan Bahasa Rupa pada Kain Batik Gendongan Lasem}

Bagian pelemahan kain batik gendongan lasem motif pohon hayat dan satwa memiliki bagian terbesar pada keseluruhan kain batik, sekitar tiga perempat bagian ornamen dari batik ini terdapat di bagian pelemahan. Oleh karena itu, pembahasan difokuskan pada analisa pada bagian tersebut. Dalam upaya memahami cerita dibalik kesatuan motif yang ada dipakai analisa cara wimba dan tata ungkapan wimba.

Seperti yang sudah disebutkan sebelumnya cara wimba adalah cara sebuah objek digambarkan, faktor yang dapat dinilai dari cara wimba atas sebuah wimba antara lain : faktor ada yang diperbesar, aneka tampak, dari kepala sampai kaki, skala, sinar ' $x$ ', dan skala (Tabrani, 2005). Setelah memahami isi wimba dan makna masing-masing menurut mitos Jawa, maka berikutnya membaca bagaimana wimba tersebut digambarkan lalu tafsir bahasa rupanya. Tata ungkapan pada sebuah wimba dianalisa berdasarkan beberapa faktor sifat yang muncul pada antar kaitan isi wimba. Faktor tersebut antara lain : apakah wimba tersebut digeser, ada kesan ruang angkasa, bentuk dinamis, gambar kembar, menggambarkan kejadian, tampak karakteristik, dan beberapa faktor lainnya. Berikut analisa cara wimba dan tata ungkapan pada ornamen pelemahan kain batik gendongan lasem, motif pohon hayat dan satwa.

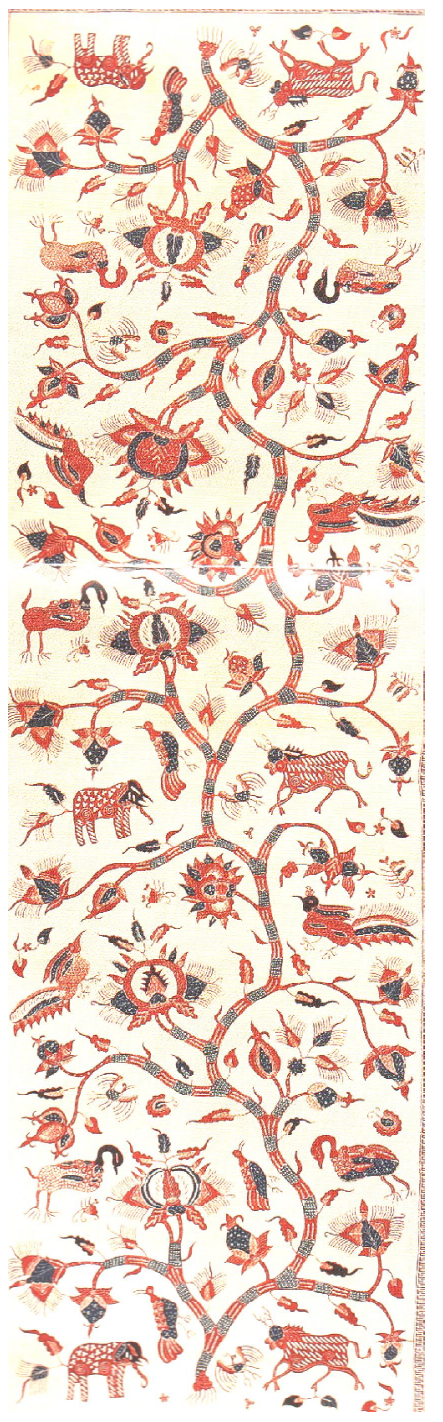

Gambar 1. Bagian Pelemahan Kain Batik Gendongan Lasem Motif Pohon Hayat dan Satwa (Sumber: Ishwara, 2011) 
Analisa Cara Wimba

Tabel 2. Cara Wimba Kain Batik Gendongan Lasem

\begin{tabular}{|c|c|}
\hline Cara Wimba & Membaca Bahasa Rupa \\
\hline \multirow[t]{2}{*}{ Ada yang diperbesar } & $\begin{array}{l}\text { Wimba pohon hayat dan bunga peony Digambar lebih } \\
\text { besar dari semua wimba yang ada. } \\
\text { Pesan yang tampak: } \\
\text { Bahwa pohon hayat dan bunga peony adalah unsur } \\
\text { paling penting bagi kehidupan alam, sebagai sumber } \\
\text { kehiudpan dari semua kehidupan. Sehingga pesan } \\
\text { utama yang ingin disampaikan oleh pembatik pada masa } \\
\text { lampau untuk pengguna kain gendongan ini adalah doa } \\
\text { bagi anak agar anak mencapai kesempurnaan, } \\
\text { kekayaan dan kemakmuran. }\end{array}$ \\
\hline & $\begin{array}{l}\text { Wimba Kerbau, adalah wimba kedua yang memiliki } \\
\text { ukuran paling besar kedua setelah motif pohon hayat, } \\
\text { Motif kerbau digambarkan lebih besar dari motif gajah, } \\
\text { padahal secara nyata bahwa gajah memiliki ukuran } \\
\text { lebih besar. Namun pada motif ini gambar kerjau } \\
\text { diperbesar, sesuai dengan teori bahasa rupa, hal ini } \\
\text { menunjukkan bahwa pesan yang ingin disampaikan } \\
\text { melalui motif kerbau lebih besar ketimbang dari } \\
\text { pesanyang ingin disampaikan melalui motif gajah. } \\
\text { Bersasarkan makna mitos orang Jawa bahwa kerbau } \\
\text { adalah perlambangan ketengangan. Oleh sebab itu, } \\
\text { harapan besar bagi anak yang digendong adalah } \\
\text { mendapatkan ketenangan. }\end{array}$ \\
\hline $\begin{array}{l}\text { Dari kepala sampai } \\
\text { kaki }\end{array}$ & $\begin{array}{l}\text { Semua wimba pada kain gendongan lasem motif pohon } \\
\text { hayat dan satwa, digambarkan dari kepala sampai kaki, } \\
\text { tidak ada yang dipotong, kesemuanya utuh. Semua } \\
\text { ornamen hewan yang ada digambarkan lengkap dari } \\
\text { kepala hingga kaki, kerbau, bebek, gajah, hingga kupu- } \\
\text { kupu. Bahkan pohon hayat pun digambar dari ujung } \\
\text { pucuk bunga hingga akar. }\end{array}$ \\
\hline \multirow[t]{2}{*}{ Aneka Tampak } & $\begin{array}{l}\text { Ornamen kerbau, burung, bebek, dan ayam semua nya } \\
\text { digambarkan tampak samping. Karena tampak } \\
\text { samping inilah bagian paling optimal dalam upaya } \\
\text { menceritakan rupa nya dengan jelas. Jika digambarkan } \\
\text { dari depan maka banyak bentuk yang hilang, seperti } \\
\text { bentuk ekor tdak bisa diperlihatkan, oleh karenaitu } \\
\text { posisi samping adalah posisi paling baik untuk bercerita } \\
\text { secara utuh. }\end{array}$ \\
\hline & $\begin{array}{l}\text { Bentuk bunga, kupu-kupu dan kalajengking } \\
\text { digambarkan tampak atas. Karena tampak atas adalah } \\
\text { posisi paling optimal untuk bentuk bunga, kupu-kupu, } \\
\text { dan kalajengking untuk menceritakan bentuknya secara } \\
\text { utuh. }\end{array}$ \\
\hline \multirow[t]{3}{*}{ Skala } & $\begin{array}{l}\text { Pohon hayat digambarkan memiliki skala lebih besar } \\
\text { dari yang aslinya, begitu juga dengan bunga. Kerbau } \\
\text { digambarkan lebih besar dari skala aslinya jika } \\
\text { dibandingkan dengan gajah. }\end{array}$ \\
\hline & $\begin{array}{l}\text { Gajah digambarkan skala yang lebih kecil dari aslinya, } \\
\text { bidandingkan dengan skala kerbau. }\end{array}$ \\
\hline & $\begin{array}{l}\text { Skala motif yang kecil digambarkan pada beberap } \\
\text { bentuk antara lain : kupu-kupu dan kalajengking. }\end{array}$ \\
\hline
\end{tabular}

Dari analisa tersebut dapat disimpulkan bahwa kain batik gendongan lasem motif pohon hayat dan satwa memiliki karakteristik bahasa rupa dimana semua faktor cara wimba terpenuhi. Pada faktor 'ada yang diperbesar' mengungkapkan makna bahwa pada motif bagian yang diperbesar memiliki arti doa/harapan paling besar bagi anak yang digendong, sedangkan pada faktor 'dari kepala sampai kaki' mengungkapkan bahwa cara penggambbaran kain batik ini digambar dengan karakter bahasa rupa timur yang bersifat primitif. Lalu pada faktor 'aneka tampak' pengrajin batik pada masa tersebut bermaksud memberikan sudut pandang terbaik dalam upaya menceritakan makna yang dibawa pada kain batik tersebut, dan faktor 'skala' merupakan upaya komunikasi prioritas peran terpenting dalam cerita yang ada pada motif batik gendongan lasem.

\section{Analisa Tata Ungkapan}

Tabel 3. Tata Ungkapan Kain Batik Gendongan Lasem

\begin{tabular}{|c|c|}
\hline Cara Wimba & Membaca Bahasa Rupa \\
\hline Digeser & $\begin{array}{l}\text { Kain gendongan lasem memiliki banyak unsur ornament } \\
\text { sehingga memiki banyak isi wimba, sebagian wimba } \\
\text { digambarkan bergeser higga terlihat dan bisa diceritakan. } \\
\text { Wimba yang digeser antara lain, kalajengking, kupu-kupu dan } \\
\text { burung huk. Adanya pergeseran berarti adanya sebuah cerita } \\
\text { yang ingin disampaikan, yaitu adanya pergerakan. }\end{array}$ \\
\hline Ruang Angkasa & $\begin{array}{l}\text { Ornamen pada kain batik gendongan digambarkan secara mirror, } \\
\text { artinya dapat gambar kesatuan dapat terlihat dari berbagai sisi. } \\
\text { Kanan, kiri, atas dan bawah. } \\
\text { Ornamen pohon hayat digambarkan berulang pada sisi kanan } \\
\text { dan kiri, hal tersebut terlihat dari adanya dua akar pohon di sisi } \\
\text { kanan dan kiri, lalu sulur tumbuhannya menyatu ditengah. } \\
\text { Ornamen binatang lainnya ikut digambarkan terbalik antara } \\
\text { kanan dan kiri, hal ini menceritakan adanya gerakan berkeliling } \\
\text { dari hewan-hewan tersebut. }\end{array}$ \\
\hline $\begin{array}{l}\text { Bentuk dinamis, } \\
\text { blabar ekspresif }\end{array}$ & $\begin{array}{l}\text { Garis yang digambar pada kain batik gendongan lasem, adalah } \\
\text { garis dinamis dan ekspresif. Terlihat dari penggambaran kaki } \\
\text { kerbau yang tidak lurus namun melengkung, hal ini menceritakan } \\
\text { bahwa hewan ini sedang menggerakkan kakinya untuk berlari. } \\
\text { Gestur yang ditampilkan adalah gestur berlari kencang. Sebagian } \\
\text { besar wimba binatang yang ada di dalam batik tersebut } \\
\text { digambarkan dengan dinamis. } \\
\text { Begitu juga dengan garis pada sulur batang pohon yang } \\
\text { digambarkan sangat dinamis, artinya pohon ini senantiasa } \\
\text { bergerak. }\end{array}$ \\
\hline $\begin{array}{l}\text { Bentuk tubuh relatif } \\
\text { statis }\end{array}$ & $\begin{array}{l}\text { Terdapat pula beberapa wimba yang digambarkan relatif statis, } \\
\text { salah satunya adalah wimba ornament gajah. Kaki depan gajah } \\
\text { nampak statis dan terdiam, hal ini dapat diartikan bahwa } \\
\text { pergerakan gajah tidak banyak atau gajah sedang kelelahan dan } \\
\text { berhenti sejenak. Gerakan gajah tidak terlihat lebih dinamis } \\
\text { dengan gambar kerbau, burung dan binantang lainnya. }\end{array}$ \\
\hline Kejadian & $\begin{array}{l}\text { Bukan still picture, namun pada kesatuan komposisi batik } \\
\text { menceritakan sebuah adegan dan proses, terdapat ukuran waktu. } \\
\text { Pada ornament kain batik gendongan ada ceriita tentang alam, } \\
\text { cerita tentang pohon hayat yang hidup dikelilingi oleh banyak } \\
\text { hewan, mulai dari hewan darat (kerbau, gajah, bebek dan ayam), } \\
\text { hewan tanah (kalajengking), hingga hewan udara (burung dan } \\
\text { kupu-kupu). Hal ini mengisahkan tentang keharmonisan hidup di } \\
\text { alam. }\end{array}$ \\
\hline Tampak karakteristik & $\begin{array}{l}\text { Semua bagian wimba pada kain batik gendongan digambarkan } \\
\text { dengan tampak karakteristiknya, sesuai dengan cara wimba yang } \\
\text { digambarkan dengan aneka tampak. } \\
\text { Kerbau, gajah, bebek, ayam dan sulur pohon digambarkan } \\
\text { dengan tampak samping, tampak yang paling mudah dikenali. } \\
\text { Kupu-kupu, kalajengking, dan bunga digambarkan dalam tampak } \\
\text { atas. }\end{array}$ \\
\hline
\end{tabular}

Berdasarkan tabel analisa tata ungkapan di atas, dapat disimpulkan, bahwa hampir dari semua faktor tata ungkapan bahasa rupa pada kain batik gendongan lasem motif pohon hayat dan satwa tersebut memenuhi setiap karakteristik bahasa rupa timur atau bahasa rupa primitif yang didalamnya terkandung cerita. Cerita tersebut menggambarkan bagaimana kehidupan di alam, dimana pohon hayat sebagai tumbuhan menjadi sumber kehidupan bagi hewan yang ada disekitarnya. Hewan yang disekitarnya hidup bebas bergerak mengelilingi pohon hayat yang juga tumbuh dengan subur. Para pembatik 


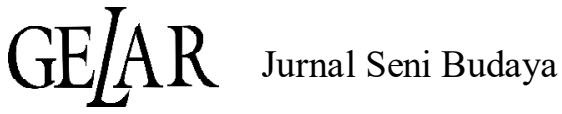

pada masanya, menggambarkan setiap ornamen dengan tata ungkapan wimba pada kain batik gendongan lasem dengan maksud menyusun cerita tentang keharmonisan alam sehingga menjadi doa dan harapan baik bagi pemakainya.

\section{Kesimpulan}

Kain batik gendongan lasem motif pohon hayat dan satwa merupakan kain batik klasik yang saat ini sudah tidak diproduksi lagi oleh para pembatik di Lasem. Kekuatan kain batik gendongan Lasem tersebut salah satunya ada pada keunikan dan kekayaan ornamen yang digambarkan di keseluruhan permukaan batiknya, khususnya ada bagian pelemahan (bagian tengah kain gendongan). Kesatuan ornamen pada kain batik gendongan Lasem motif pohon hayat dan satwa, memiliki karaktertistik bahasa rupa primitif dimana didalamnya mengandung cerita yang tidak bebatas ruang, tempat, dan waktu. Para pembatik pada masa tersebut bermaksud menceritakan sebuah kisah tentang keindahan alam, dimana pohon hayat tumbuh dengan harmonis dengan hewan-hewan lainnya. Ini adalah sebuah bentuk komunikasi dari para pembatik pada jamannya untuk memberikan pengharapan yang baik bagi para pemakainya, khususnya bagi ibu dan anak yang menggunakan kain gendongan tersebut.

Dari cara isi wimba, cara wimba, tata ungkapan yang ada pada kain batik lasem tersebut dapat djadikan inspirasi berkarya bagi para desainer batik lainnya untuk dapat menghasilkan karya yang tidak sekedari baik secara estetis namun memiliki makna kuat. Diharapkan hasil analisa ini dapat digunakan sebagai pertimbangan bagi para pembatik dan desainer lainnya dalam merancangan desain motif baru. Bagi para pembatik Lasem tidak hanya untuk mengungkapkan sejarah, namun juga mengungkap makna dan maksud cerita dari para pembatik masa lalu, serta diharapkan dapat meneruskan dan mengenalkan keunikan dari kain batik gendongan Lasem, serta harapan untuk semakin meramaikan industri batik di Lasem.

\section{KEPUSTAKAAN}

Hout, I.C. Van. 2015. Beloved Burden : Babywearing Around the World. LM Publisher.

Ishwara, Helen. Yahya, L.R. Supriyapto. Moeis, Xenia. 2011. Batik Pesisir Pusaka Indonesia. Jakarta : KPG.

Kusrianto, Adi. 2013. Batik Filosofi, Motif dan Kegunaan. Yogyakarta : C.V Andi Offset.

Maulany, Nazala Noor. Masruroh, Nur Naelil. 2017. "Kebangkitan Industri Lasem di awal Abad XXI". Jurnal Patrawidya, Vol. 18. No 1 (April $20017: 1-12$.

Pujiyanto. 2003. "Mitologi Jawa dalam Motif Batik Unsur Alam". Jurnal Bahasa dan Seni. Tahun 31, Nomor 1. (Februari 2003) : 128-141.

Rahayu, Murniasih Dwi. Alrianingrum, Septina. 2014. "Perkembangan Motif Batik Lasem Cina Peranakan Tahun 1900-1960". AVATARA,ejournal Pendidikan Sejarah. Vol. 2, No. 2 (Juni 2014): 36-49.

Rahayu, Kanti. 2008. Upaya Perlindungan Batik Lasem oleh Pemerintah Kabupaten Rembang. Tesis S2. Pascasarjana IImu Hukum. Universitas Dipeonegoro.

Sumarsono, H. 2011. Batik Pesisir Pustaka. Jakarta: KPG.

Tabrani, Primadi. 2005. Bahasa Rupa. Bandung: Kelir. 